\title{
Ovarian Collision Tumors
}

\author{
Shanmugam Sujithra ${ }^{1}$, Usha Rani ${ }^{2}$, Sandhya Sundaram ${ }^{3}$, Rajendiran $\mathrm{S}^{4}$, Susruthan $\mathrm{M}^{5}$
}

\begin{abstract}
Background: A collision tumor is the coexistence of two distinct tumors without any histological intermixing in the same organ or tissue. Though these types of tumors are often seen in various organs, their occurrence in the ovary is rare.

Case description: Here, we have reported a case series of three collision tumors-serous cystadenoma with mature cystic teratoma, mucinous cystadenoma with benign cystic teratoma, and a case of serous cystadenofibroma with mature cystic teratoma.

Clinical significance: It is important to identify collision tumors and also document all their components for optimal treatment.

Keywords: Collision tumor, Mucinous cystadenoma, Serous cystadenoma, Teratoma.

Journal of South Asian Federation of Obstetrics and Gynaecology (2020): 10.5005/jp-journals-10006-1851
\end{abstract}

\section{Case Descriptions}

\section{Case 1}

A 16-year-old girl came with complaints of pain abdomen on and off for the past 1 month and complaints of abdominal fullness for 1 month. On per abdominal examination, there was a $30 \times 20 \mathrm{~cm}$ globular cystic mass palpable up to epigastrium, tense, non-mobile, nontender with a smooth surface.

CA 125 done was $50 \mathrm{mlU} / \mathrm{mL}$. CT scan showed a large cystic lesion in the pelvis, extending up to epigastrium of size $29.2 \times 18.8$ $\mathrm{cm}$. The right ovary was not visualized separately. Fat component with calcification was seen suggestive of right dermoid cyst (Fig. 1).

The patient underwent laparoscopic cystectomy. Intraoperative findings showed right ovarian cyst of size $30 \times 25 \mathrm{~cm}$ of mixed consistency. Cyst wall biopsy was sent for frozen section and was reported as a benign lesion. Right ovarian cystectomy was done and a portion of the right ovary near the hilum was preserved. Cut section of the cyst showed few strands of hair and calcified structure were seen in one area of the cyst wall (Figs 2 and 3).

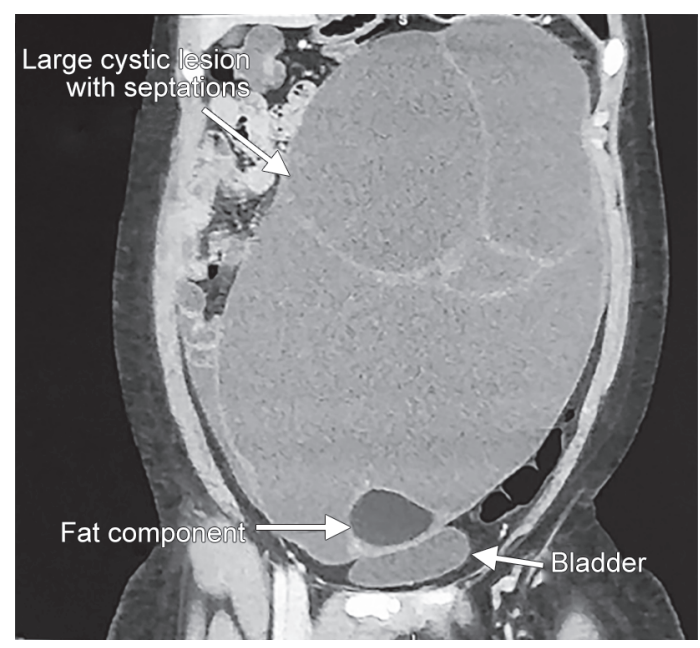

Fig. 1: CT scan report showing cystic lesion with septations and fat component with calcification suggestive of dermoid cyst

\begin{abstract}
1,2Department of Obstetrics and Gynaecology, Sri Ramachandra Institute of Higher Education and Research, Chennai, Tamil Nadu, India

${ }^{3-5}$ Department of Pathology, Sri Ramachandra Institute of Higher Education and Research, Chennai, Tamil Nadu, India

Corresponding Author: Usha Rani, Department of Obstetrics and Gynaecology, Sri Ramachandra Institute of Higher Education and Research, Chennai, Tamil Nadu, India, Phone: +9198410 67790, e-mail: usha_jagan2003@yahoo.com

How to cite this article: Sujithra S, Rani U, Sundaram S, et al. Ovarian Collision Tumors. J South Asian Feder Obst Gynae 2020;12(5):331-334.

Source of support: Nil

Conflict of interest: None
\end{abstract}

Final histopathological examination showed ovarian stroma focally lined by a single layer of low cuboidal epithelium consistent with serous cystadenoma. However, an additional section from a different area showed keratin flakes with hair follicles (Figs 4 and 5). Hence, the diagnosis of collision tumor consisting of serous cystadenoma and mature cystic teratoma was rendered.

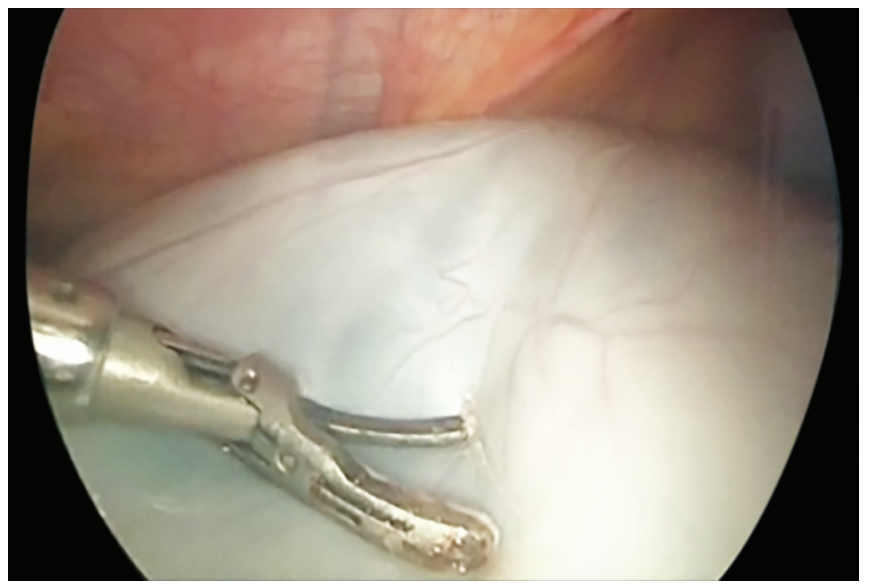

Fig. 2: Intraoperative picture showing smooth-walled cyst extending up to epigastrium

\footnotetext{
(c) Jaypee Brothers Medical Publishers. 2020 Open Access This article is distributed under the terms of the Creative Commons Attribution 4.0 International License (https://creativecommons.org/licenses/by-nc/4.0/), which permits unrestricted use, distribution, and non-commercial reproduction in any medium, provided you give appropriate credit to the original author(s) and the source, provide a link to the Creative Commons license, and indicate if changes were made. The Creative Commons Public Domain Dedication waiver (http://creativecommons.org/publicdomain/zero/1.0/) applies to the data made available in this article, unless otherwise stated.
} 


\section{Case 2}

A 32-year-old parous woman came with complaints of menstrual irregularity and lower abdominal pain for the past 4 months. Per abdomen examination did not reveal any mass. On per vaginal examination, the uterus was found to be of normal size with right forniceal fullness. Transvaginal ultrasound done showed right complex adnexal cyst of size $10.2 \times 11.9 \times 8.9 \mathrm{~cm}$ with internal septations and solid components.

The patient underwent open right ovarian cystectomy. Intraoperatively, a right ovarian cyst of size $12 \times 10 \mathrm{~cm}$ with mucinous material was noted. A solid nodule was present at the base of the ovarian cyst. Cyst wall biopsy sent for frozen section came to be mucinous cystadenoma with benign cystic teratoma. Right ovarian cystectomy was done and the specimen was sent for histopathological examination.

Final histopathological examination showed mucinous cystadenoma of right ovary lined by a single layer of mucinous epithelium with the area of calcification and bone with keratinous material suggestive of mucinous cystadenoma with mature cystic teratoma (Figs 6 and 7).

\section{Case 3}

A 56-year-old parous woman who is postmenopausal for 10 years came with complaints of lower abdominal pain for 3 months.

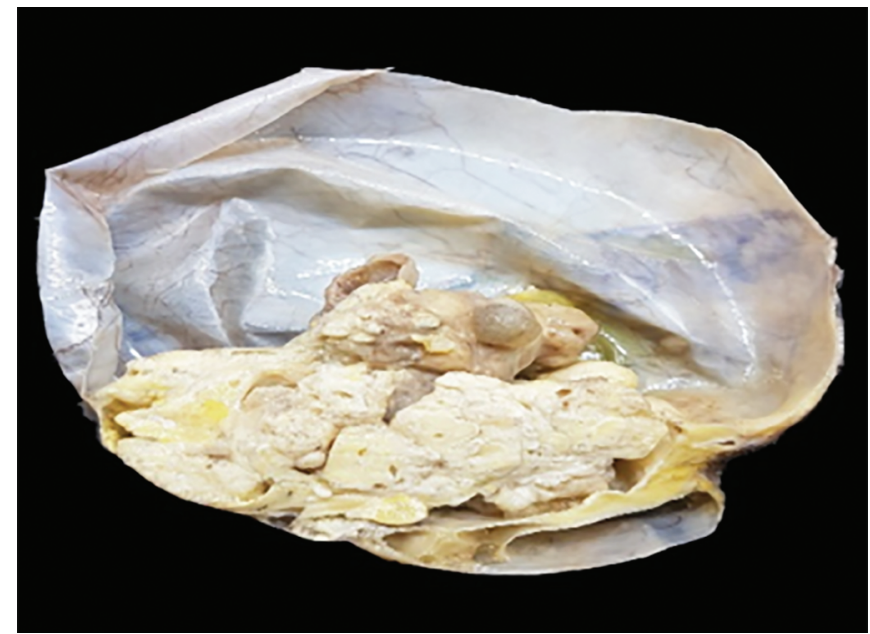

Fig. 3: Gross picture showing grayish-white smooth cyst wall with a focal area of thickening and calcification

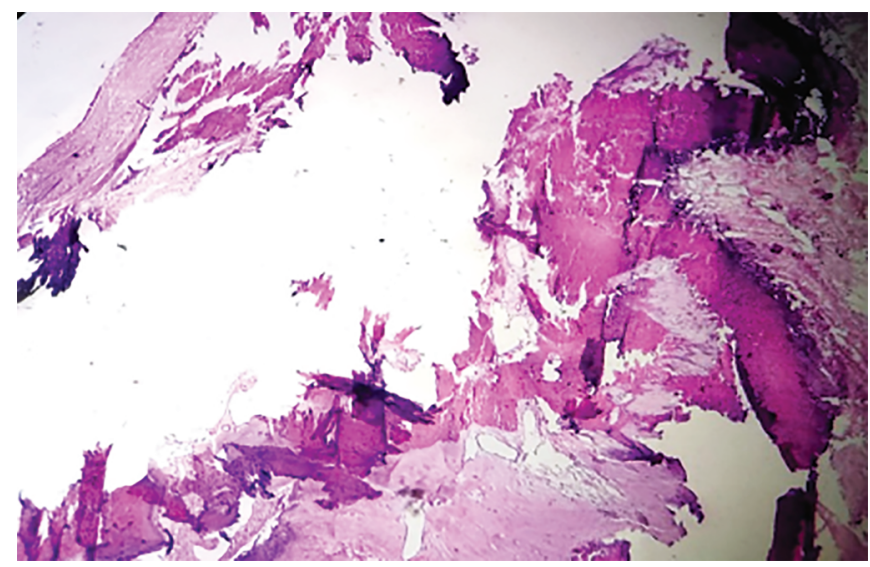

Fig. 5: Another separate area showing keratin flakes with hair follicles ( $\times 100$ H\&E stain)
On examination, the abdomen was soft. A mobile, nontender right adnexal mass was noted in per vaginal examination. MRI pelvis showed a cystic mass lesion of size $11 \times 9.8 \times 10.6 \mathrm{~cm}$ in the right adnexa with few septations suggestive of benign right ovarian cyst. The right ovary could not be imaged separately (Fig. 8).

The patient underwent a total abdominal hysterectomy with bilateral salpingo-oophorectomy. Intraoperative findings showed a right ovarian cyst of size $12 \times 14 \mathrm{~cm}$.

Final histopathological examination showed features of serous cystadenofibroma with small foci of mature squamous epithelial cells with skin adnexa and mature adipose tissue suggestive of collision tumor consisting of serous cystadenofibroma with benign cystic teratoma (Fig. 9).

\section{Discussion}

A collision tumor is the coexistence of two distinct tumors in the same organ without any histological intermixing.

Although uncommon, these types of tumors have been reported in various organs like the gastrointestinal tract, lung, skin, adrenals, central nervous system, lymph nodes, uterus, etc., but are relatively rare in the ovary. The most common component of a collision tumor is a mature cystic teratoma.

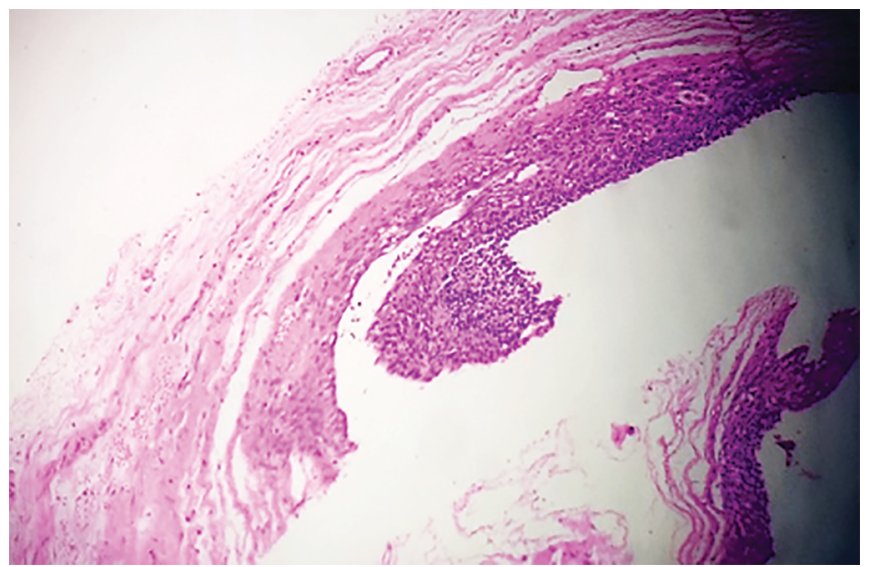

Fig. 4: Ovarian stroma focally lined by a single layer of low cuboidal epithelium ( $\times 200$ H\&E stain)

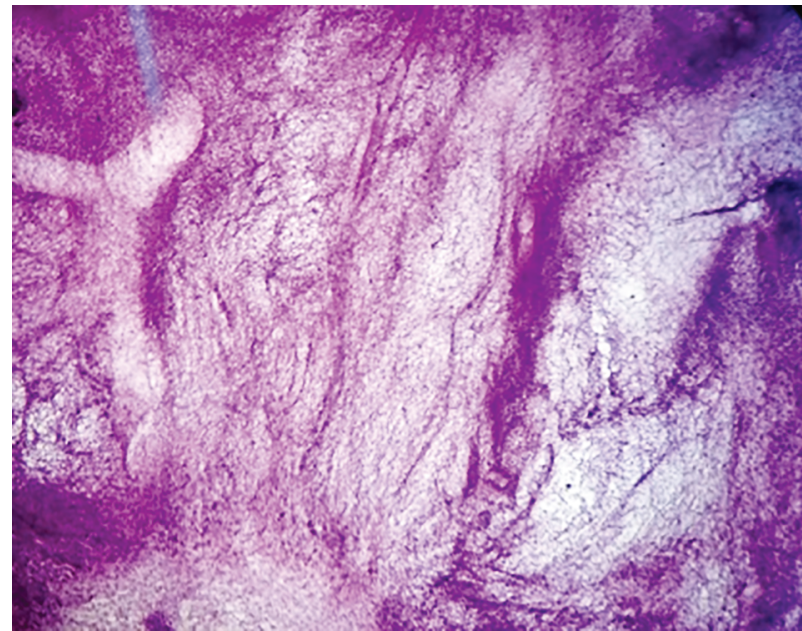

Fig. 6: Mucinous cystadenoma of ovary lined by a single layer of mucinous epithelium ( $\times 200 \mathrm{H} \&$ E stain) 


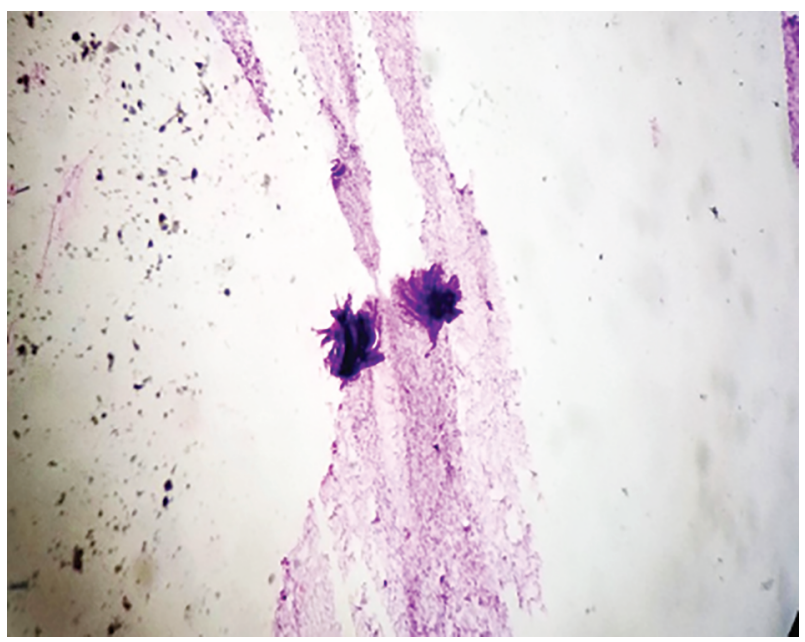

Fig. 7: Area of calcification and bone with keratinous material $(\times 200$ H\&E stain)

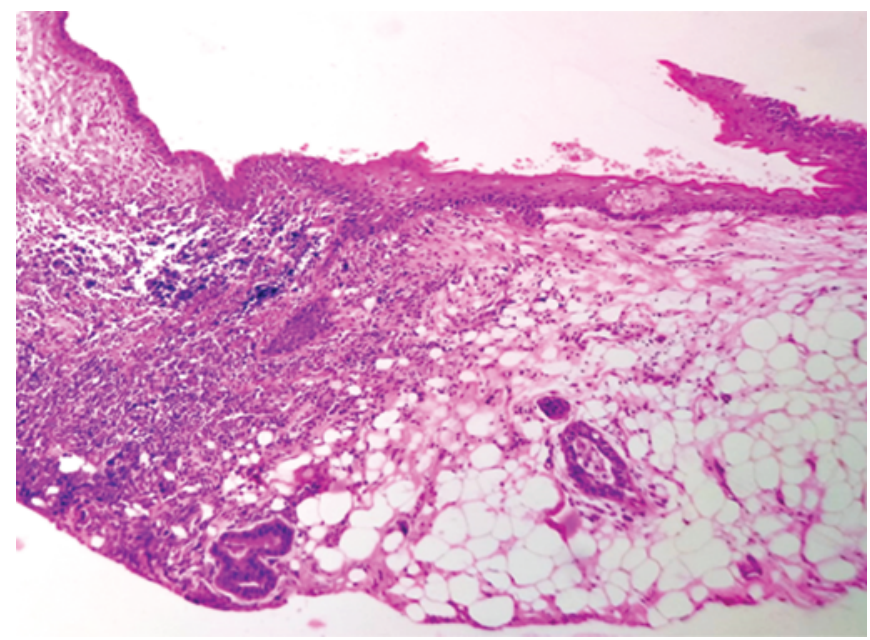

Fig. 9: Serous cystadenofibroma with small foci of mature squamous epithelial cells with skin adnexa and mature adipose tissue $(\times 200 \mathrm{H} \& \mathrm{E}$ stain)

The coexistence of tumors with varying histogeneses in the ovary has been described in the literature, such as serous cystadenoma and teratoma, ${ }^{2}$ mucinous cystadenoma and teratoma, ${ }^{2}$ serous adenocarcinoma and steroid cell tumor, ${ }^{3}$ serous papillary cystadenocarcinoma and granulosa cell tumor, ${ }^{4}$ and teratoma with granulosa cell tumor. ${ }^{5}$ The most common combination of collision tumor is mucinous tumors and teratomas. ${ }^{6-8}$

There are various hypotheses for the formation of collision tumors, such as:

- There can be a simultaneous proliferation of two different cell lines as described by Bige et al. as "chance accidental meeting".

- Common origin from a pluripotent stem cell. ${ }^{1}$

- The presence of the first tumor alters the microenvironment which leads to the development of the second primary tumor or seeding of metastatic tumor cells. ${ }^{1}$

- A carcinogenic agent interacting with different tissues and inducing different tumors. ${ }^{3}$

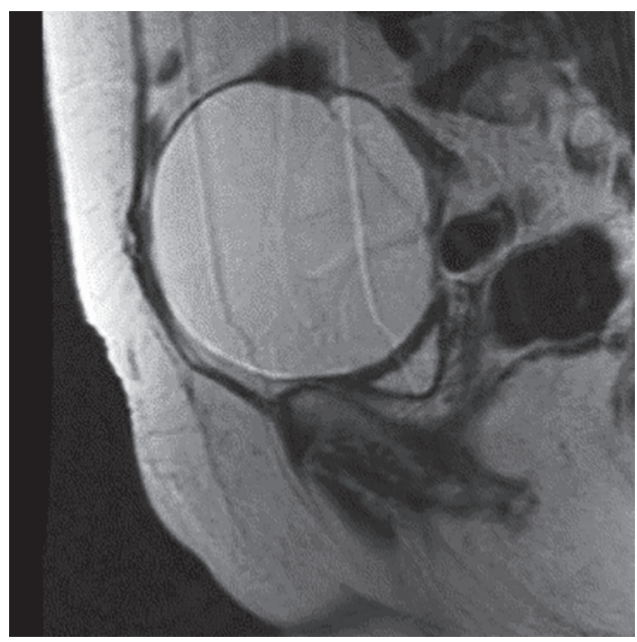

Fig. 8: MRI pelvis showing a cystic mass lesion of size $11 \times 9.8 \times 10.6 \mathrm{~cm}$ in right adnexa with few septations

Collision tumors should be differentiated from composite tumors where there is intermixing of tumor lines, such as, in malignant mixed Mullerian tumors. ${ }^{9}$

Collision tumors are mostly diagnosed postoperatively with the help of histopathological examination. Patterson et al. found that most of the collision tumors had radiologic clues, such as, the presence of non-fatty fluid in the cyst and a large solid component in the ovarian mass, which pointed toward the presence of two different tumors in the same ovary. ${ }^{10,11}$ When an ovarian teratoma has imaging findings that cannot be explained solely by an ovarian teratoma, the possibility of a collision tumor should be considered. ${ }^{6}$

Adequate excision and meticulous histopathological examination need to be done for understanding the various components of collision tumors to avoid them being misdiagnosed as malignancy.

\section{Conclusion}

Though collision tumor of the ovary is very rare, the pathologist and surgeons should be aware of the existence of such tumors. Radiological clues and their confirmation in a frozen section can help in avoiding unnecessary extensive surgeries.

\section{References}

1. Bige O, Demir A, Koyuncuoglu M, et al. Collision tumor: serous cystadenocarci-noma and dermoid cyst in the same ovary. Arch Gynecol Obstet 2009;279(5):767-770. DOI: 10.1007/s00404-008-07816.

2. Singh AK, Singh M. Collision tumours of ovary: a very rare case series. J Clin Diagn Res 2014;8(11):FD14-FD16. DOI: 10.7860/ JCDR/2014/11138.5222.

3. Nirenberg A, Ostor AG, Quinn MA. Collision tumor: serous adenocarcinoma and steroid cell tumor of the ovary. Pathol 1992;24(2):60-62. DOI: 10.3109/00313029209063624.

4. Ozbey C, Erdogan G, Pestereli HE, et al. Serous papillary adenocarcinoma and adult granulosa cell tumor in the same ovary. APMIS 2005;113(10):713-715. DOI: 10.1111/j.1600-0463.2005. apm_255.x.

5. Dgani R, Rozenman D, Lifschnitz-Mercer B. Granulosa cell tumor arising in an ovary with mature cystic teratoma. Int $J$ Gynaecol Obstet 1993;41(3):287-289. DOI: 10.1016/0020-7292(93)90562-B. 
6. Kim SH, Kim YJ, Park BK, et al. Collision tumors of the ovary associated with teratoma: clues to the correct preoperative diagnosis. J Comput Assist Tomogr 1999;23(6):929-933. DOI: 10.1097/00004728$199911000-00017$.

7. Tang P, Soukkary S, Kahn E. Mature cystic teratoma of the ovary associated with complete colonic wall and mucinous cystadenoma. Ann Clin Lab Sci 2003;33:465-470.

8. Tiezzi DG, Guimaraes DG, Oguido EG, et al. Mucinous cystadenocarcinoma of low malignant potential coexisting with a mature cystic teratoma: A case report. Rev Bras Ginecol Obstet 2003;25:605-608.
9. Lewin K. Carcinoid tumour and mixed (composite) glandular-endocrine cell carcinomas. Am J Surg Pathol 1987;11(Supplement 1):71-86. DOI: 10.1097/00000478-19870011100007.

10. Patterson DM, Murugaesu N, Holden L, et al. A review of the close surveillance policy for stage I female germ cell tumors of the ovary and other sites. Int J Gynecol Cancer 2008;18(1):43-50. DOI: 10.1111/j.1525-1438.2007.00969.x.

11. Bichel P. Simultaneous occurrence of a granulosa cell tumour and a serous papillary cystadenocarcinoma in the same ovary. A case report. APMIS 1985;93:175-181. 